\title{
What Should Be the EU's Approach to Global Trade?
}

The world trading system faces contestation at an unprecedented level. The United States, once a fundamental pillar for free trade and multilateral trade order, has changed course and joined the countries who have voiced a chorus of concerns about globalisation. The various actors' motivations for contestation may differ greatly (social and environmental effects on the one side, bilateral trade disequilibria on the other), but what they all have in common is the perception of unfairness and negative side effects. It follows that the progression of globalisation can no longer be taken for granted and that globalisation, and world trade as part of it, may be downscaled or unwound in the future.

The European Union, which has been a staunch supporter of multilateralism in international trade, finds itself in a setting in which trade disputes risk spiralling into trade wars and the international rules-based trade order is cast in to doubt. The role of the $\mathrm{EU}$, which is a major player in the world trade arena given its market size and openness to trade, has become pivotal. However, it cannot simply defend the current system.

Rather, the EU faces a twin challenge: it seeks to uphold a rules-based international order, while perhaps less obviously but we would argue crucially, shaping the future world trade order. The latter requires that the EU project its values (enshrined in the European model that aims at making growth compatible with social and environmental protection) onto the global stage through its trade policy. The challenge is especially acute with respect to the still largely ignored link between trade and the environment.

\section{Risk of trade wars}

Global trade and growth have undoubtedly benefited greatly from the multilateral framework drawn up under the auspices of the General Agreement on Tariffs and Trade (GATT) and its successor, the World Trade Organization (WTO). It has encountered sizable problems that await resolution, however, as indicated by the increasingly difficult conclusion of mul-

Annette Bongardt, London School of Economics and Political Science, UK; and Universidade Fernando Pessoa, Porto, Portugal.

Francisco Torres, London School of Economics and Political Science, UK; and Católica Lisbon School of Business \& Economics, Lisbon, Portugal. tilateral trade rounds (which culminated in the demise of the Doha Round in 2005) and growing frustration with what some consider the unfair practices of their trading partners (most notably China) $)^{1}$. As a result, the world has witnessed a proliferation of bilateral and regional trade deals through which countries aim to further their trade interests more directly.

More recently, multilateralism and the idea of international trade as a win-win situation received another severe blow when the current US administration shifted to an "America First" stance with a bilateral, zero-sum perspective on and approach to extracting benefits from trade..$^{2}$ It may serve as an illustration that in the course of trying to address its concerns and push its interests with selected trading partners, the US declared its long-standing ally, the EU, a foe. It suspended the negotiated EU-US Transatlantic Trade and Investment Partnership (TTIP), did not sign the Trans-Pacific Partnership Agreement (TPP - subsequently signed by the remaining TPP11 partners under the designation of the Comprehensive and Progressive Agreement for Trans-Pacific Partnership, CPTPP), and renegotiated an existing plurilateral trade agreement with only one partner at a time - the North American Free Trade Agreement (NAFTA). In addition, the US has threatened trade partners with and embarked on imposing import trade tariffs. Those unilateral measures have met with retaliation, among others by China and the EU, who have imposed import duties on a range of US products in response to US tariffs on EU steel and aluminium. It also raised the possibility of tit-for-tat trade wars - with the EU, but currently most acutely with China.

Citing discontentment with the way the WTO oversteps its competences - a concern that the EU shares to a certain extent - the US has taken actions e.g. blocking the nomination of judges to arbitration panels, that jeopardise the WTO's dispute settlement mechanism, which is central to the multilateral rules-based trade order. The WTO has warned that this, together with the US entering into trade conflicts with the rest of the world, risks damaging the WTO as a guarantor of the

(C) The Author(s) 2018. Open Access: This article is distributed under the terms of the Creative Commons Attribution 4.0 International License (https://creativecommons.org/licenses/by/4.0/), which permits unrestricted use, distribution, and reproduction in any medium, provided you give appropriate credit to the original author(s) and the source, provide a link to the Creative Commons license, and indicate if changes were made.

1 While the WTO would have been well placed to extract concessions from China at the time it was to join, China has since become a major global trading force.

2 This became very clear at the June 2018 G7 meeting in Montreal, Canada. Even the possibility of the US withdrawing from the WTO is no longer unthinkable. 
international system and imperils world trade. ${ }^{3}$ While the task of reforming an international organisation of 164 members, which have different interests but take decisions by unanimity, is a steep and cumbersome one that is only possible by building the necessary cross-country consensus, it is in the EU's interest to ensure a workable trade order. In our view, however, the EU's approach to global trade should not stop there.

\section{Credibility and compromise}

First and foremost, the EU is seeking to uphold free trade, de-escalate trade conflicts and defuse looming trade wars. In doing so, it is treading a fine line in its trade policy. For a global player like the EU, it must adequately respond to US unilateral actions and not give in to threats in order to preserve its credibility. However, it is not in its interest to let trade conflicts escalate and be drawn into trade wars. Those are costly in real terms, as the European Central Bank (ECB) warns, due to the serious risk they pose to activity in the short to mediumterm and to the outlook for global trade. ${ }^{4}$ The EU opted to engage with the US and to find some common ground; there are obviously some shared interests and concerns, such as WTO reform and market access discrimination and intellectual property right protection in China. Bilateral trade remains important, regardless of the fact that TTIP, a comprehensive trade agreement aimed at creating a common transatlantic marketplace with low barriers to trade and investment, ultimately was the only EU agreement that did not advance. TTIP is currently on hold by decision of the current US administration. The EU-US trade deal was hotly contested in the EU and proved unsellable in light of the reach of third country regulatory autonomy on EU territory.

The EU has pursued two parallel courses of action. To start with, it attempts to negotiate a settlement with the US on the WTO. The EU regards the WTO, in particular its role in global trade disputes, as vital for upholding a rules-based international trading order. Since no clarity exists as to whether the US administration intends to reform the WTO or do away with it, the EU drew up reform proposals that take up the kind of complaints that the US has raised, to be presented to the WTO this month (September 2018). This move allows the EU to test the US' willingness to work constructively on its critiques (and consequently lift its opposition to the judges on dispute settlement panels) or otherwise call its bluff with regard to its stated commitment to engage with the EU on WTO reform.

3 Declarations by Roberto Azevedo, Director-General of the WTO: Warum wir die Welthandelsorganisation WTO brauchen, Handelsblatt, 9 August 2018.

4 European Central Bank, Economic Bulletin No. 5, 9 August 2018, available at https://www.ecb.europa.eu/pub/economic-bulletin/html/ eb201805.en.html.
At the same time, the EU has, rather successfully, sought to augment and strengthen its trade ties and to strategically close ranks with like-minded trading partners. ${ }^{5}$ The shared concern - the new US stance did not only raise the EU's resolve to sustain free trade but also the importance of securing free trade for many other countries - has predictably promoted and accelerated new EU trade deals with existing and prospective trading partners. ${ }^{6}$

In light of the already rather low tariff barriers among WTO members, the EU embarked upon a new generation of international agreements. It means that in most cases, and in the absence of any one-size-fits-all trade agreement, the EU negotiates comprehensive free trade agreements with third countries. ${ }^{7}$ Recent examples of those deep free trade agreements include the EU-Canada Comprehensive and Economic Trade Agreement (CETA) and the EU-Japanese Free Trade Agreement (JEFTA), and potentially also one with the United Kingdom, once it becomes a third party to the EU. ${ }^{8}$

US protectionism boosted EU trade dynamism. Furthermore, it opened up a strategic space in which the Union could also seek to bring global trade in line with its preferences for growth with high environmental and social standards. The crucial question is to what extent is the EU willing to put this capacity to good use.

The meeting between Commission President Juncker and US President Trump on 25 July 2018 in Washington, an EU initiative, resulted in an agreement to suspend a war on trade tariffs and work toward an accord. ${ }^{9}$ It also provides clues about the EU's priorities in trade and about the kind of compromises the EU looks prepared to make in the name of external trade.

5 For an explanation of this new policy stance, see A. Bongardt, F. Torres: Comprehensive Trade Agreements: Conditioning Globalisation or Eroding the European Model?, in: Intereconomics, Vol. 52, No. 3, 2017, pp. 165-170.

6 For instance, CPTPP countries turned to the EU to make (or accelerate or deepen) free trade and investment deals. There has also been a fresh impetus for a number of free trade negotiations that were previously slow-moving or had stalled (among others with Japan, South Korea, and Mercosul) to upgrading existing ones (such as with Mexico).

7 An update of the state of play of EU free trade agreements is available at http://ec.europa.eu/trade/policy/countries-and-regions/negotiations-and-agreements/.

8 A discussion of EU international trade and Brexit can be found in A. Bongardt, F. Torres: Trade Agreements and Regional Integration: the EU after Brexit, in: R. Looney (ed.): Routledge Handbook of International Trade Agreements, London and New York 2018, Routledge, pp. 296-306.

9 See European Commission: Joint U.S.-EU Statement following President Juncker's visit to the White House, Statement/18/4687, 25 July 2018, available at http://europa.eu/rapid/press-release_STATEMENT-18-4687_en.htm. 


\section{A truce with the US, but at what price?}

The EU managed to achieve a (temporary) truce (i.e. no additional US import tariffs on cars from the EU) as long as a perspective EU-US trade agreement is negotiated without making substantial concessions to the US. The US will reassess (rather than lift) its punitive tariffs. The EU will commit to raising imports from the US in certain sectors (more soybeans to make up for reductions of US exports to China in the face of Chinese retaliations toward US policy, and more American liquefied natural gas (LNG), thereby competing with Russian gas and diversifying EU energy supplies). The parties also commit to negotiating a comprehensive tariff reduction for industrial goods and a reform of the WTO.

For the time being the truce holds but it is fragile. The scope of the agreement has turned out to be ambiguous and partly contentious within the EU (Is agriculture in or out? Is the idea to reactivate the wide TTIP or go with a reduced version of it?). ${ }^{10}$ And to cement the truce, the EU has already made further offers (higher quotas for non-hormone US beef exports, a lift on all auto tariffs if the US reciprocates). These are considered insufficient by the US.11

If we accept the argument that what matters is that the agreement ended the escalation of tit-for-tat tariffs and averted a trade war, ${ }^{12}$ then the question at what price, if any, becomes relevant. After all, any potential benefits of reviving TTIP depend heavily on doing away with regulatory barriers. ${ }^{13}$ However, TTIP was heavily contested because of the concern that any such deal might come at the expense of EU (present or future) standards (notably high sanitary, food and environmental standards).

The EU Commission has often been accused in the past of privileging trade liberalisation over societal (labour, environmental) concerns. It has hence committed to internalis-

10 The Juncker deal risks disrupting European unity. Favoured by Germany (with an automotive industry strongly exposed to US sanctions), France rejects a wide TTIP-style agreement and the inclusion of agriculture. It is also opposed to the EU negotiating while sanctions are active. In any case, renewed trade would require a negotiation mandate for the Commission and the European Parliament would also have a word to say (limiting the role of expert groups).

11 Perhaps more importantly in practice, the US is already experiencing that in today's globalised world (with features like complex supply chains), trade policy can be a twin-edged sword, so that tariffs hurt not only foreign but also domestic economic agents through more expensive inputs, and that trade partners retaliate against punitive tariffs, and prefers to focus more on China for the time being.

12 D. Gros: Europe's Trade Coup, Project Syndicate, 6 August 2018.

13 W. Connell, W. Simons, H. Vandenbussche: The cost of non-TTIP: A Global Value Chain Approach, CEPR Discussion Paper No. 12705, February 2018, argue that the costs of non-TTIP are even larger if one takes into account complex global value chains. Yet, they also conclude that while those potential benefits are substantial, they derive less from the abolition of tariff barriers than from non-tariff measures. ing those concerns in trade and to protecting the EU's high standards. The EU-US agreement could jeopardise this however. The EU abandoned its customary defence of the Paris Climate Agreement and of environmental standards for the sake of achieving a suspension of US trade sanctions. And although any concessions may appear symbolic since higher imports of US soybeans and LNG rest on market decisions, those are two areas that happen to be rather sensitive on environmental grounds (genetically modified agricultural products and gas produced through fracking). The objective to internalise environmental externalities on efficiency and environmental grounds and to work toward the European model through external trade appears to have been sidelined in the name of trade.

Pragmatism that privileges trade over European values does not bode well for the defence of the European model in trade. In the face of vocal criticism of the negative side effects of international trade, combined with the rise of populism, ${ }^{14}$ the EU needs to shape globalisation in order to make it work for its citizens and deliver results that are in line with European values and objectives. Even though some progress has been made, the European Commission needs to fully internalise those values in its trade policy as well and actively push for them or face backlash.

\section{External trade and EU regulation}

Any discussion on what should be the EU's approach to global trade needs to take into account that external trade and regulation interact and impact on the European model. The EU's new generation of deep trade agreements magnifies the issue of regulation, which is already complex in internal EU trade in an international trade context. ${ }^{15}$

The economic case for EU comprehensive trade agreements rests on realising largely untapped benefits from abolishing non-tariff barriers to trade. Trade and welfare effects are complex and may even be ambiguous. Although conditioned by the scope of the agreements in question, e.g., covering areas like public or regulated services, intellectual property rights and investment protection, they tend to have broader implications for society and influence its model of development.

\footnotetext{
14 The success of anti-EU populist parties in continental Europe, especially in France, derives partly from opposition to a (Anglo-Saxontype) deregulated economic model and a neglect of the European model. It stresses the importance of fairness for the success of the European economy and of the European project. The social chapter is an expression of the EU seeking to complete its model in the social sphere. See A. Bongardt, F. Torres: The road towards a genuine Economic and Monetary Union: more competitive and fairer, in: F. Allemand, P. Chiocchetti (eds.): Competitiveness and Solidarity in the European Union: Interdisciplinary Perspectives, Abingdon, Routledge, forthcoming.

15 A. Bongardt, F. Torres: Comprehensive Trade Agreements, op. cit.
} 
This is because the inclusion of non-tariff barriers to trade - and of other issues such as investment protection - interferes with political preferences on the role of the state in the economy and highlights the role of regulation. ${ }^{16}$ This is also intrinsically political as it is based on values and beliefs. Acceptance is not a given and ratification is more complex and uncertain once they encroach on member state competences. ${ }^{17}$ The market making versus market correcting issue that features prominently in the internal market context is an even larger topic in deep free trade agreements.

What made regulation-based integration possible in the EU, economically and politically speaking, was sufficient similarity of preferences or, in its absence, the societal acceptability of mutual recognition of national market rules. Mutual recognition is the fall back solution in light of European varieties of capitalism. It implies competition between regulatory systems that presupposes a degree of trust in other countries to ensure the rules will be similar in their effect and supervision as well as enforcement capacity to function. Regulatory arbitrage has proven problematic at times even in a European context as the EU has become more heterogeneous over time. To the extent that comprehensive agreements come to constrain market correction, they can reinforce negative integration tendencies in the EU by putting downward pressure on standards through trade. To hope otherwise would require a notion of similarity with regard to third countries that is already stretched within the Union.

The CETA case illustrated that rules on regulation in comprehensive trade agreements, such as through regulatory cooperation, mutual recognition or investment court arbitration, may come to limit the European and national policy space. Those were also key elements in the contestation of TTIP.18

16 Most EU-level rules currently refer to risk regulation, which pursues safety, health, environmental and consumer protection objectives. This risk regulation concerns mostly goods and services markets - for example financial market regulation and supervision, and network industry aspects - and only sporadically labour and capital markets. On a more horizontal level, it includes environmental regulation and consumer protection and rights. The precautionary principle, enshrined in the treaties, is an important EU principle in this context. The rejection of the original Services Directive, based on the home country principle, well illustrated the political difficulties even within the (with increasing membership ever more heterogeneous) EU club.

17 The Court of Justice of the European Union clarified the distribution of competences between member states and the EU in its verdict on the Singapore agreement. A comprehensive trade agreement qualifies as a mixed agreement (like CETA) and hinges not only on ratification at the EU level but also at the EU member state, and in some cases, regional level. CETA has been applied provisionally since the second half of 2017 but is still awaiting ratification by all member states. JEFTA, the EU's largest comprehensive trade agreement so far, was signed in July 2018. It could enter into force as of the beginning of 2019 if things went to plan.

18 The EU had been prepared to go further under TTIP with the US than the US had been under TPP, with deeper agreement on regulatory issues, covering three broad areas, namely market access, regulatory issues and non-tariff barriers, and rules.
Public contestation of the EU's new generation of comprehensive trade agreements sits uneasily with EU trade dynamics. TTIP and CETA, in particular, crystallised popular opinion regarding the negative effects of globalisation on European society and the environment. The backlash against the effects of globalisation were then directed at the Union, which was perceived as prioritising economic (commercial) interests over societal concerns.

It is worth noting that through the bilateral rules established in the context of a comprehensive trade agreement, the EU not only influences global norms and standards but that those in turn feed back into the EU's economic order in a way that traditional trade agreements have not. They can therefore either reinforce the European model or weaken it. The matter is economically and politically sensitive at a time when the European model, as a result of the limited progress of the EU's economic and institutional modernisation agenda - and on the belated implementation of the social pillar - is still not consolidated.

\section{Sustainable rules and value-based trade order}

At this junction for world trade, the approach that the EU takes to global trade will define its credibility as a global actor and impact the sustainability of the European integration project. The issue is whether the Union will actively work towards a rules-based international order, which delivers on EU preferences for quality growth and fairness and which prioritises the overdue link between environmental sustainability and trade. Economic growth cannot be sustained over time if the limits of the planet are not accounted for; nor is trade sustainable if negative externalities are not factored in. The EU's self-declared leadership role in combating climate change provides a test case for its resolve.

Bilateral trade agreements offer the EU an easier and speedier way to advance European goals and project its values onto the global stage than multilateral forums. On the downside, they could also lower environmental and labour standards and give multinational firms the power to challenge national laws and limit the EU's and member states' regulatory space. A trade focus may easily lead the EU to overlook the complex and potentially broad consequences for society of economic and trade agreements. The recent experience indicates that the EU only belatedly integrated the environment and the Paris Climate Agreement in the South Korea free trade agreement and in JEFTA, ${ }^{19}$ respectively, and that

19 Adherence to the Paris Climate Agreement was also only belatedly introduced upon French insistence, and without much detail. As B. Unmüssig, M. Kellner: A Climate-Friendly Response to Trump's Protectionism, Project Syndicate, 4 June 2018, observe, the EU could also enhance its climate leadership credentials by adopting border carbon adjustment rules, which are in line with WTO rules. 
it abandoned the climate issue to achieve a trade truce with the US.

Yet, with the US' commitment to the international trading order increasingly cast in doubt, the EU has a unique op- portunity to be an anchor of an international rules and value-based system. That would mean to push notably for high labour, environmental and climate standards in trade agreements, something that the European Commission has embraced in theory but seemingly not yet in practice. 